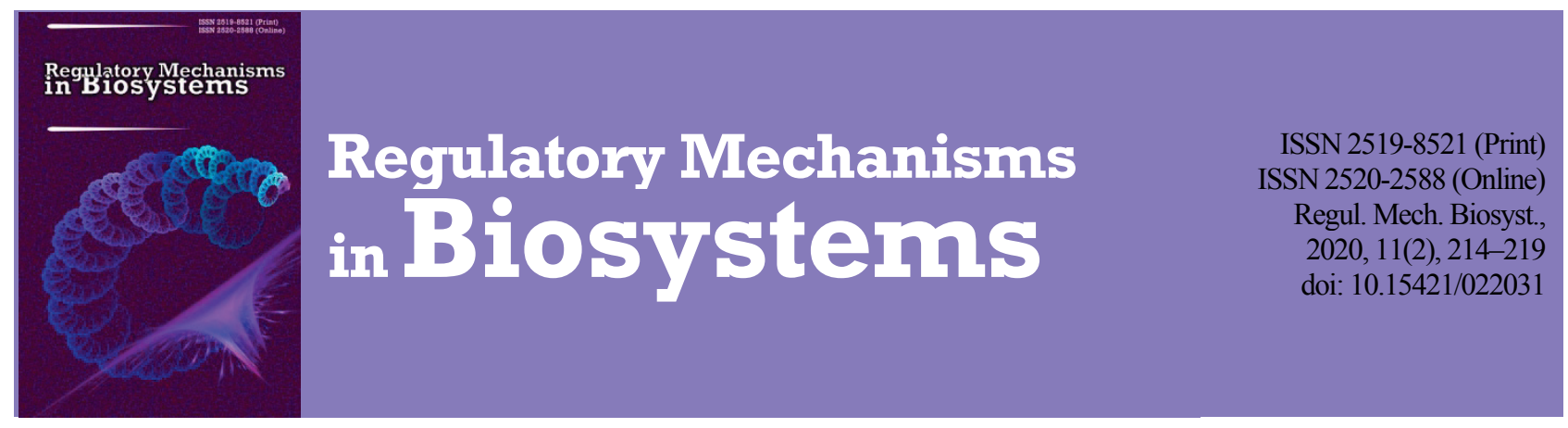

\title{
The lipid metabolism in carp during invasion by the tapeworn Bothriocephalus acheilognathi
}

\author{
L. L. Yuskiv, I. D. Yuskiv \\ Stepan Gzhytskyj Lviv National University of Veterinary Medicine and Biotechnologies, Lviv, Ukraine
}

Article info

Received 04.03.2020

Received in revised form 15.04.2020

Accepted 16.04.2020

Stepan Gzhytskyj

Lviv National University

of Veterinary Medicine

and Biotechnologies,

Pekarska st., 50

Lviv, 79000, Ukraine.

Tel.: +38-063-223-36-22.

E-mail:

igoryuskiv@ukr.net

\section{Yuskiv, L. L., \& Yuskiv, I. D. (2020). The lipid metabolism in carp during invasion by the tapeworn Bothriocephalus acheilognathi. Regulatory Mechanisms in Biosystems, 11(2), 214-219. doi:10.15421/022031}

The changes in total lipids, their fatty acid composition and the ratio of individual classes were established in tissues of the intestine, hepatopancreas and skeletal muscles of carp (Cyprinus carpio Linnaeus, 1758), with body weight 14.5-20.5 g, at different rates of invasion by Bothriocephalus acheilognathi (Yamaguti, 1934) helminth, which belongs to the family Bothriocephalidae, of the Pseudophyllidae order, of the Cestoda class. The examined carp was divided into three groups: first group of fish was free from intestinal helminths of B. acheilognathi (control); second group of fish was weakly infected with helminths (intensity of invasion is 1-3 helminths per fish); the third group of fish was highly infected (the invasion intensity is 4 worms and more per fish). Our results showed that fish infected with helminth $B$. acheilognathi compared to uninfected fish had reduced total lipid level in the gut due to phospholipids, triacylglycerols, and also lipids were characterized by lower content of linoleic, linolenic, arachidonic, penta- and hexanoic fatty acids; decrease in the level of unsaturated and increase in the content of saturated fatty acids, which leads to an increase of the saturation factor. During the infection of carp with B. acheilognathi in the hepatopancreas, the content of total lipids, structural lipids - phospholipids and reserve energy sources - triacylglycerols is probably reduced, and lipids are characterized by a high content of saturated fatty acids (C14:0, C16:0, C18:0) and lower content of unsaturated: arachidonic (C20:4), linolenic (C18:3) and linoleic acid (C18:2), which is associated with a decrease in the source for the synthesis of a number of polyunsaturated fatty acids, especially docosahexaenoic (C22:6). The total content of lipids, triacylglycerols, free fatty acids and phospholipids in skeletal muscle of carp during the Bothriocephalus invasion decreased and the content of free cholesterol, mono- and triacylglycerols increased. Helminth $B$. acheilognathi has the effect of reducing the total lipids of the skeletal muscle content of C18-, C20-, C22-polyunsaturated fatty acids and increasing the content of saturated (C14:0, C16:0, C18:0) and monounsaturated (C16:1, C18:1) fatty acids. The obtained results prove that the parasite $B$. acheilognathi in the intestine of the carp significantly affects the nutrition processes of the host depending on the intensity of the damage by helminths, which is accompanied by impaired lipid metabolism.

Keywords: fatty acids; intestine; hepatopancreas; skeletal muscle; metabolism; Bothriocephalidae; Pseudophyllidae.

\section{Introduction}

Ecosystems are a complex of living organisms that have adapted to joint living in a particular habitat, forming a whole with it. Living organisms interact directly and indirectly, forming the basis for many ecosystem properties and processes, such as the nutrient cycle (Agrawal et al., 2007). Health and disease represent two basic forms of the life process. Health status and disease can change constantly throughout the life of a fish, the one exceeding the other on many occasions. During its lifetime the body of a fish is exposed to different environmental influences: fluctuations of hydrological and hydrochemical parameters, pathogens of diseases, etc. (Marenkov, 2018). In the host-parasite interaction, the feeder population develops protective mechanisms to avoid parasites, and parasites develop counter-adaptation to overcome the protection mechanisms of the host, which leads to a tight joint evolution of the host-parasite (Klein, 2005). Therefore individuals are constantly adjusting to change of external factors and irritants, which means adaptation. Adaptation mechanisms are aimed at supporting homeostasis, that is the equilibrium state of the organism with the external environment (Davies, 2016).

Research on adaptation mechanisms of the organism to the environment is a topical issue in biochemistry and physiology. All adaptation processes are based on biochemical adaptations, that is the ability of living systems to adapt to changing conditions of the environment due to modifications of their biochemical structure and metabolic reactions. In biochemical adaptation of a living organism, lipids and their components have an important role. The role of lipids in cellular metabolism is manysided. However, there are three main functions of lipids: energy, structural and bioeffective (act as messengers), that are the most studied (Murzina et al., 2013). It is known, that the successful development of aquaculture facilities depends on the resistance of fisheries to diseases. In industrial fish breeding in pond farms of Ukraine the invasive disease of bothriocephalosis is widely disseminated (Pukalo \& Shek, 2018). Cestodoses infestation most often occurs in one-year old carp (Ahmad et al., 2018; Kuchta et al., 2018). Partial occlusion and damage of the intestinal mucosa by helminths leads to disruption of execution functions of the digestive tract: suction, barrier, the emission of digestive secretions decreases (Britton et al., 2011). During the infection of fish with Bothriocephalus, the intestines are not sufficiently filled with food or are completely empty, which leads to the reduced growth and development of carp (Hansen et al., 2006; Scholz et al., 2012). However the catarrhal-hemorrhagic enteritis caused by cestodes combined with the action of their exchange products, that are absorbed through the intestinal wall into the bloodstream and further into the hepatopancreas, causes fatty dystrophy and changes in metabolic processes (Britton et al., 2011; Gaikwad et al., 2016).

Among the criteria for evaluation of the quality of fishery products are indicators of lipid metabolism, dependent on feeding and environmental conditions (Hansen et al., 2006; Hu et al., 2016; Murzina et al., 2016). Fish are weakened as a result of Bothriocephalus invasion and poorly adapted to the mobilization of spare body substances as a source of energy during winter. In fish adaptation processes one of the main roles is played by 
lipids, which combine a lot of organic compounds, performing different functions in energy and plastic exchange (Hrytsyniak et al., 2010; Dey et al., 2015). This leads to increased usage of endogenous substrates during energy processes in fish tissues, in particular fatty acids, which are released in the process of cleavage of triacylglycerols, deposited in the liver and adipose tissue (Hrytsyniak et al., 2010; Murzina et al., 2020). In addition, one of the reasons of decrease in fish productivity of ponds could be abnormalities in lipid metabolism, its direction and intensity, providing fish adaptation to Bothriocephalus invasion. The role of individual metabolites, including lipids, in the physiological and biochemical features of hydrobionts should be determined in order to understand the ability of organisms to survive in changing conditions (Murzina et al., 2013).

This determines the relevance of research, aimed at clarifying the changes in the content of lipids and their fatty acid composition in the tissues of carp during the Bothriocephalus invasion, since their survival in the winter largely depends on the deposition of fat in skeletal muscle. Thereby the purpose of our work was to investigate the effect of different intensities of $B$. acheilognathi invasion on the total content of lipids, their fatty acid composition and the ratio of individual classes in the intestines, hepatopancreas and skeletal muscles of the carp.

\section{Materials and methods}

The research was conducted at the Department of Parasitology and Ichthyopathology of Lviv National University of Veterinary Medicine and Biotechnologies and the Institute of Animal Biology (Lviv). The object of the study was carp (Cyprinus carpio Linnaeus, 1758) from growing ponds with different intensities of $B$. acheilognathi helminth infestation. For this purpose, three groups of this-year carp were formed. Fish free from intestinal cestodes (B. acheilognathi), control rules (first group). The fish of the second group were weakly infected with helminths (intensity of invasion is 1-3 helminths per fish), and the third group of fish was highly infected (the invasion intensity is 4 worms and more per fish). Carp weight ranges $14.5-20.5 \mathrm{~g}$. The intestinal wall, hepatopancreas and muscle samples of the anterior apical part of the back, which were obtained immediately after the decapitation of the fish after catching them from the ponds were taken for research. Tissue samples were frozen in liquid nitrogen. Samples from medium-sized tissue samples, each of which was part of a sample of tissues from six fish, were taken for biochemical research. We used four medium samples of fish tissue of each group $(n=4)$ for research.

The determination of total lipid content in biological materials were performed by the Falch method (Folch et al., 1957; Vlizlo et al., 2012) with a mixture of chloroform with methanol in a ratio of $2: 1$. Determination of individual lipid classes content in tissues was performed by thin layer chromatography on ascending silica gel solvent stream hexanediethyl ether-glacial acetic acid $(70: 30: 1)$ (Kates, 1975; Vlizlo et al., 2012), followed by the detection of individual classes by treating the plates in iodine vapors (Stahl, 1965; Vlizlo et al., 2012). The quantitative determination of lipid classes (phospholipids, di- and triacylglycerols, free fatty acids, free and esterified cholesterol) was made with the dichromate method, by determining the colour intensity on a spectrophotometer at a wavelength of $490 \mathrm{~nm}$ (Arkhipov \& Antonov, 1979; Vlizlo et al., 2012). Fatty acid composition of total lipids was determined by the gas-liquid chromatography method (Sidorov et al., 1991; Vlizlo et al., 2012) using a "Chromium-4" chromatograph.

The analysis of obtained data was performed using Statistica 6.0 software (StatSoft Inc., USA). Tables demonstrate the results in form of $\mathrm{x} \pm$ standard deviation. Differences between values in control and study groups were determined by using ANOVA, where $\mathrm{P}$ a value less than 0.05 (taking into account the Bonferroni error) was considered as statistically significant.

\section{Results}

Changes in lipid content that depended on the intensity of the infection were detected in the tissue of intestines of fish during $B$. acheilognathi infestation (Table 1). The presence of Bothriocephalus in the gut of carp caused a statistically significant lower lipid content from 10.37 (uninfected fish) to $6.20 \mathrm{~g} \%$ in second group with infected intensity of $1-3$ parasites per fish and up to $3.78 \mathrm{~g} \%$ in third group with an infected intensity of 4 or more parasites per fish. When the intestines are clogged with cestodes (they fill about $1 / 3-2 / 3$ of the digestive tract) the partial supply of nutrients from the outside is stopped, and mobilizing energy sources, that will be used during the winter, are insufficiently stored in different fat depots of fish.

\section{Table 1}

Total lipid content and ratio of their individual classes in the intestines of the investigated fish, not infected and infected with $B$. acheilognathi $(\mathrm{x} \pm \mathrm{SD}, \mathrm{n}=4)$

\begin{tabular}{|c|c|c|c|}
\hline Lipid classes & $\begin{array}{l}\text { Uninfected, } \\
\text { control } \\
\text { first group }\end{array}$ & $\begin{array}{l}\text { 1-3 parasites } \\
\text { per fish } \\
\text { second group }\end{array}$ & $\begin{array}{l}>3 \text { parasites } \\
\text { per fish } \\
\text { third group }\end{array}$ \\
\hline $\begin{array}{l}\text { Total lipids, } \mathrm{g} \% \\
\quad \text { Lipid classes, } \%\end{array}$ & $10.37 \pm 0.65$ & $6.20 \pm 0.52^{* *}$ & $3.78 \pm 0.57 * * *$ \\
\hline Phospholipids & $42.48 \pm 0.93$ & $38.14 \pm 0.63^{* *}$ & $36.41 \pm 1.22^{* *}$ \\
\hline $\begin{array}{l}\text { Mono- and } \\
\text { diacylglycerols }\end{array}$ & $16.97 \pm 0.96$ & $19.21 \pm 0.67$ & $25.47 \pm 1.02^{* * *}$ \\
\hline Free cholesterol & $8.60 \pm 0.80$ & $10.36 \pm 0.88$ & $11.38 \pm 0.63 *$ \\
\hline Free fatty acids & $14.26 \pm 1.30$ & $13.88 \pm 0.39$ & $9.40 \pm 0.92 *$ \\
\hline Triacylglycerols & $13.37 \pm 0.71$ & $12.97 \pm 1.26$ & $10.92 \pm 0.79^{*}$ \\
\hline Cholesterol esterified & $4.33 \pm 0.30$ & $5.47 \pm 0.73$ & $6.42 \pm 0.84 *$ \\
\hline
\end{tabular}

Notes: $*-\mathrm{P}<0.05 ; * *-\mathrm{P}<0.01 ; * * *-\mathrm{P}<0.001$ relative to controls (including Bonferroni correction)

The amount of total phospholipids in uninfected intestinal tissue was $42.5 \%$, and in infected intestinal tissue was lower by $10.2 \%(\mathrm{P}<0.01)$ in the second group and lower by $14.3 \%(\mathrm{P}<0.001)$ in the third group. The content of the fraction of triacylglycerols herewith decreased in infected fish, respectively by $3.0 \%$ and $18.3 \%(\mathrm{P}<0.05)$, as well as free fatty acids, respectively, by $2.7 \%$ and $34.1 \%(\mathrm{P}<0.05)$. At the same time the concentration of free and esterified cholesterol and mono- and diacylglycerols increased. It is important to say that the greater intensity of infection of fish with Bothriocephalus, the more expressed the process.

The data presented in Table 2 shows that the fatty acid composition of total lipids tissue of intestinal tissue of carp depends on the intensity of infection by parasites. In both groups of infected fish the same tendency is observed to increase in the amount of saturated fatty acids due to myristic (C14:0), pentadecanoic (C15:0), margaric (C17:0) and especially palmitic $(\mathrm{C} 16: 0)$ and stearic $(\mathrm{C} 18: 0)$ which are relatively uninfected.

In cestodes of fish the most clear increase is noted in the content of oleic acid $(\mathrm{C} 18: 1, \mathrm{P}<0.05 ; \mathrm{P}<0.01)$. This indicator in the gut tissue of infected fish compared to uninfected increased by $12.9 \%$ in the second group and $19.6 \%$ in the third group. The content of other monounsaturated fatty acids also increased: palmitoleic $(\mathrm{C} 16: 1, \mathrm{P}<0.05)$, heptadecenoic $(\mathrm{C} 17: 1)$. At the same time in infected fish there was a significant decrease in polyunsaturated acids: linoleic $(\mathrm{C} 18: 2, \mathrm{P}<0.01 ; \mathrm{P}<0.001)$, linolenic (C18:3, $\mathrm{P}<0.05 ; \mathrm{P}<0.001)$, arachidonic (C20:4, $\mathrm{P}<0.01 ; \mathrm{P}<0.001)$, decosahexaenoic $(\mathrm{C} 22: 6, \mathrm{P}<0.05 ; \mathrm{P}<0.001)$ was observed. In the absence of linoleic acid, carp cannot synthesize other polyunsaturated acids of $\omega 3$ series, which leads to increase in oleic and palmitic acids.

The research has shown that the lipid composition of the hepatopancreas undergoes changes depending on the intensity of $B$. acheilognath infection (Table 3 ). In the hepatopancreas of carp infected by $1-3$ parasites per fish the concentration of total lipids decreased relative to uninfected by $24.9 \%(\mathrm{P}<0.01)$, and in carp infected with 4 or more parasites per fish by $63.2 \%(\mathrm{P}<0.001)$. Reduced lipid concentration in the hepatopancreas of infected fish is obviously connected to the changes their membrane structure and therefore their permeability.

For individual lipid classes, it should be noted that in the second and third experimental groups, compared to control, a lower level of phospholipids, triacylglycerols, free fatty acids $(\mathrm{P}<0.05)$ was observed. It is important to mention, the increase in concentration of free and esterified cholesterol in hepatopancreas $(\mathrm{P}<0.05)$, which perform a stabilizing function in biological membranes, as well as mono- and diacylglycerols $(\mathrm{P}<0.01)$.

A difference between infected and not infected fish has been identified in the fatty acid composition of lipids (Table 4). In the hepatopancreas of infected fish the amount of saturated fatty acids increases on account of palmitic $(\mathrm{C} 16: 0) 8.8 \%$ in the second group and $12.5 \%(\mathrm{P}<0.05)$ in the 
third group, respectively, myristic (C14:0) on $17.5 \%(\mathrm{P}<0.01)$ and $31.3 \%$ $(\mathrm{P}<0.01)$ and stearic acid $(\mathrm{C} 18: 0)$ on $14.8 \%(\mathrm{P}<0.05)$ and $20.1 \%(\mathrm{P}<$ $0.05)$, which are synthesized in the body. Increased biosynthesis of individual saturated fatty acids in the hepatopancreas is perhaps associated with the adaptive reactions of the fish body to $B$. acheilognathi infection.

Table 2

The content of fatty acids of total lipids in the intestines of the investigated fish, not infected and infected with $B$. acheilognathi $(\%, \mathrm{x} \pm \mathrm{SD}, \mathrm{n}=4)$

\begin{tabular}{|c|c|c|c|}
\hline Fatty acid code & $\begin{array}{l}\text { Uninfected, } \\
\text { control }\end{array}$ & $\begin{array}{l}1-3 \text { parasites } \\
\text { per fish }\end{array}$ & $\begin{array}{l}>3 \text { parasites } \\
\text { per fish }\end{array}$ \\
\hline $\mathrm{C}_{14.0}$ & $0.70 \pm 0.01$ & $0.81 \pm 0.01 * * *$ & $0.84 \pm 0.02 * * *$ \\
\hline $\mathrm{C}_{14: 1}$ & $0.34 \pm 0.05$ & $0.37 \pm 0.03$ & $0.40 \pm 0.04$ \\
\hline $\mathrm{C}_{15: 0}$ & $0.78 \pm 0.02$ & $0.85 \pm 0.01 *$ & $0.91 \pm 0.02 * *$ \\
\hline $\mathrm{C}_{16: 0}$ & $20.00 \pm 0.54$ & $21.75 \pm 0.60$ & $23.02 \pm 0.64^{*}$ \\
\hline $\mathrm{C}_{16: 1}$ & $6.49 \pm 0.37$ & $7.58 \pm 0.15^{*}$ & $7.75 \pm 0.10^{*}$ \\
\hline $\mathrm{C}_{17: 0}$ & $0.88 \pm 0.03$ & $1.03 \pm 0.04^{*}$ & $1.24 \pm 0.05^{* * *}$ \\
\hline $\mathrm{C}_{17: 1}$ & $0.53 \pm 0.03$ & $0.56 \pm 0.03$ & $0.73 \pm 0.06^{*}$ \\
\hline $\mathrm{C}_{18: 0}$ & $10.60 \pm 0.49$ & $10.93 \pm 0.44$ & $12.20 \pm 0.38^{*}$ \\
\hline $\mathrm{C}_{18: 1}$ & $24.65 \pm 0.84$ & $27.83 \pm 0.69^{*}$ & $29.47 \pm 0.92 * *$ \\
\hline $\mathrm{C}_{182}$ & $22.45 \pm 0.80$ & $17.86 \pm 0.83^{*}$ & $14.74 \pm 0.97 * * *$ \\
\hline $\mathrm{C}_{183}$ & $0.95 \pm 0.03$ & $0.84 \pm 0.03 *$ & $0.67 \pm 0.03 * * *$ \\
\hline $\mathrm{C}_{20: 1}$ & $2.01 \pm 0.06$ & $1.89 \pm 0.07$ & $1.74 \pm 0.06^{*}$ \\
\hline $\mathrm{C}_{202}$ & $1.02 \pm 0.04$ & $0.93 \pm 0.04$ & $0.82 \pm 0.03^{* *}$ \\
\hline $\mathrm{C}_{203}$ & $0.79 \pm 0.05$ & $0.53 \pm 0.03 * *$ & $0.49 \pm 0.04^{* *}$ \\
\hline $\mathrm{C}_{20: 4}$ & $2.43 \pm 0.09$ & $1.90 \pm 0.09 * *$ & $1.53 \pm 0.10^{* * *}$ \\
\hline $\mathrm{C}_{20,5}$ & $0.74 \pm 0.02$ & $0.68 \pm 0.03$ & $0.56 \pm 0.03^{* *}$ \\
\hline $\mathrm{C}_{223}$ & $0.18 \pm 0.04$ & $0.19 \pm 0.03$ & $0.15 \pm 0.03$ \\
\hline $\mathrm{C}_{22: 4}$ & $0.53 \pm 0.04$ & $0.44 \pm 0.05$ & $0.43 \pm 0.04$ \\
\hline $\mathrm{C}_{225}$ & $0.58 \pm 0.05$ & $0.44 \pm 0.04$ & $0.42 \pm 0.02 *$ \\
\hline $\mathrm{C}_{22: 6}$ & $2.82 \pm 0.07$ & $2.16 \pm 0.05^{* * *}$ & $1.47 \pm 0.09 * * *$ \\
\hline $\mathrm{C}_{24: 1}$ & $0.53 \pm 0.01$ & $0.43 \pm 0.03 *$ & $0.32 \pm 0.02 * * *$ \\
\hline$\sum$ saturated FA & $32.96 \pm 3.85$ & $35.37 \pm 4.15$ & $38.21 \pm 4.41$ \\
\hline$\sum$ unsaturated FA & $67.04 \pm 2.05$ & $64.63 \pm 2.06$ & $61.79 \pm 2.08^{*}$ \\
\hline$\sum$ monounsaturated FA & $34.54 \pm 3.90$ & $38.66 \pm 4.43$ & $40.51 \pm 4.69$ \\
\hline$\sum$ polyunsaturated FA & $32.50 \pm 2.15$ & $25.97 \pm 1.71^{*}$ & $21.28 \pm 1.41^{* * *}$ \\
\hline $\begin{array}{l}\text { Saturated FA / } \\
\text { unsaturated FA }\end{array}$ & 0.49 & 0.55 & 0.61 \\
\hline
\end{tabular}

Notes: see Table 1.

Table 3

Total lipid content and ratio of their individual classes in the hepatopancreas of the investigated fish, not infected and infected with $B$. acheilognathi $(\mathrm{x} \pm \mathrm{SD}, \mathrm{n}=4)$

\begin{tabular}{lccc}
\hline \multicolumn{1}{c}{ Lipid classes } & $\begin{array}{c}\text { Uninfected, } \\
\text { control }\end{array}$ & $\begin{array}{c}1-3 \text { parasites } \\
\text { per fish }\end{array}$ & $\begin{array}{c}>3 \text { parasites } \\
\text { per fish }\end{array}$ \\
\hline $\begin{array}{l}\text { Total lipids, g\% } \\
\quad \text { Lipid classes, } \%\end{array}$ & $20.58 \pm 1.04$ & $15.46 \pm 1.14^{* *}$ & $7.57 \pm 0.85^{* * *}$ \\
Phospholipids & $47.98 \pm 0.71$ & $45.36 \pm 0.58^{*}$ & $44.08 \pm 0.86^{*}$ \\
Mono- and & $11.30 \pm 0.62$ & $14.50 \pm 0.54^{* *}$ & $16.63 \pm 0.88^{* *}$ \\
diacylglycerols & $6.47 \pm 0.84$ & $9.61 \pm 0.54^{*}$ & $10.20 \pm 0.57^{*}$ \\
Free cholesterol & $12.83 \pm 1.00$ & $9.04 \pm 0.62^{*}$ & $8.59 \pm 0.87^{*}$ \\
Free fatty acids & $17.46 \pm 1.14$ & $15.35 \pm 1.34$ & $14.16 \pm 0.74^{*}$ \\
Triacylglycerols & $3.96 \pm 0.50$ & $6.14 \pm 0.76$ & $6.34 \pm 0.76^{*}$ \\
Cholesterol esterified & & & \\
\hline
\end{tabular}

Notes: see Table 1.

A particularly pronounced difference was revealed in the ratio of the reserve of essential fatty acids, having an alimentary origin. In the hepatopancreas of infected fish the amount of arachidonic acid (C20:4) decreased in second group by $18.9 \%(\mathrm{P}<0.01)$ and in the third group by $48.0 \%$ $(\mathrm{P}<0.001)$, and, respectively, of linoleic $(\mathrm{C} 18: 2)$ by $14.4 \%(\mathrm{P}<0.01)$ and by $25.3(\mathrm{P}<0.001)$ and linolenic $(\mathrm{C} 18: 3)$ by $20.5 \%(\mathrm{P}>0.01)$ and $40.9 \%$ $(\mathrm{P}<0.05)$, which serve as a source of synthesis for a number of polyunsaturated fatty acids. In the lipids we found a reduction in the proportion of concentrations of pentaenoic fatty acids and especially docosahexaenoic acid (C22:6) by $43.9 \%$ in the second group $(\mathrm{P}<0.001)$ and $63.8 \%$ in the third group $(\mathrm{P}<0.001)$ compared to not infected fish.

In not infected fish, the total content of saturated fatty acids of lipids was $33.3 \%$, while in the infected Bothriocephalus second group it was $36.6 \%$ and in third group $38.0 \%$, that of unsaturated fatty acids, respectively, $66.7 \%, 63.4 \%$ and $62.0 \%$, the unsaturation coefficient was 0.50 , 0.58 and 0.61 , respectively.
Table 4

The content of fatty acids of total lipids of hepatopancreas of the investigated fish, not infected and infected with $B$. acheilognathi $(\%, \mathrm{x} \pm \mathrm{SD}, \mathrm{n}=4)$

\begin{tabular}{|c|c|c|c|}
\hline Fatty acid code & $\begin{array}{l}\text { Uninfected, } \\
\text { control }\end{array}$ & $\begin{array}{l}\text { 1-3 parasites } \\
\text { per fish }\end{array}$ & $\begin{array}{l}>3 \text { parasites } \\
\text { per fish }\end{array}$ \\
\hline $\mathrm{C}_{14: 0}$ & $0.80 \pm 0.02$ & $0.94 \pm 0.03^{* *}$ & $1.05 \pm 0.04 * *$ \\
\hline $\mathrm{C}_{14: 1}$ & $0.19 \pm 0.01$ & $0.22 \pm 0.02$ & $0.24 \pm 0.02$ \\
\hline $\mathrm{C}_{15: 0}$ & $0.26 \pm 0.01$ & $0.32 \pm 0.02 *$ & $0.36 \pm 0.03 *$ \\
\hline $\mathrm{C}_{16: 0}$ & $20.56 \pm 0.49$ & $22.37 \pm 0.69$ & $23.12 \pm 0.62^{*}$ \\
\hline $\mathrm{C}_{16: 1}$ & $5.43 \pm 0.16$ & $6.03 \pm 0.16^{*}$ & $6.13 \pm 0.20^{*}$ \\
\hline $\mathrm{C}_{17: 0}$ & $0.99 \pm 0.06$ & $0.72 \pm 0.02 * *$ & $0.67 \pm 0.04 * *$ \\
\hline $\mathrm{C}_{17: 1}$ & $0.55 \pm 0.02$ & $0.53 \pm 0.01$ & $0.51 \pm 0.02$ \\
\hline $\mathrm{C}_{18: 0}$ & $10.67 \pm 0.46$ & $12.25 \pm 0.38^{*}$ & $12.82 \pm 0.55^{*}$ \\
\hline $\mathrm{C}_{18: 1}$ & $37.30 \pm 0.72$ & $38.56 \pm 0.66$ & $39.78 \pm 0.68^{*}$ \\
\hline $\mathrm{C}_{1822}$ & $10.25 \pm 0.33$ & $8.36 \pm 0.38^{* *}$ & $7.66 \pm 0.24 * * *$ \\
\hline $\mathrm{C}_{18: 3}$ & $0.44 \pm 0.05$ & $0.36 \pm 0.03$ & $0.26 \pm 0.02 *$ \\
\hline $\mathrm{C}_{20: 1}$ & $3.75 \pm 0.10$ & $2.99 \pm 0.07 * * *$ & $2.64 \pm 0.10^{* * *}$ \\
\hline $\mathrm{C}_{20: 2}$ & $1.10 \pm 0.06$ & $0.80 \pm 0.03^{* *}$ & $0.76 \pm 0.04 * *$ \\
\hline $\mathrm{C}_{20: 3}$ & $0.68 \pm 0.04$ & $0.58 \pm 0.03$ & $0.55 \pm 0.02 *$ \\
\hline $\mathrm{C}_{20: 4}$ & $2.81 \pm 0.07$ & $2.28 \pm 0.06^{* *}$ & $1.46 \pm 0.08^{* * *}$ \\
\hline $\mathrm{C}_{20.5}$ & $0.24 \pm 0.02$ & $0.22 \pm 0.03$ & $0.18 \pm 0.01 *$ \\
\hline $\mathrm{C}_{22: 3}$ & $0.14 \pm 0.06$ & $0.12 \pm 0.05$ & $0.08 \pm 0.02$ \\
\hline $\mathrm{C}_{22: 4}$ & $0.39 \pm 0.04$ & $0.28 \pm 0.03$ & $0.28 \pm 0.05$ \\
\hline $\mathrm{C}_{22: 5}$ & $0.25 \pm 0.09$ & $0.20 \pm 0.09$ & $0.18 \pm 0.08$ \\
\hline $\mathrm{C}_{22: 6}$ & $2.87 \pm 0.11$ & $1.61 \pm 0.08^{* * *}$ & $1.04 \pm 0.10^{* * *}$ \\
\hline $\mathrm{C}_{24: 1}$ & $0.33 \pm 0.02$ & $0.27 \pm 0.01 *$ & $0.23 \pm 0.01 * *$ \\
\hline $\begin{array}{l}\text { saturated FA } \\
\text { s }\end{array}$ & $33.28 \pm 3.97$ & $36.60 \pm 4.38$ & $38.02 \pm 4.54$ \\
\hline$\sum$ unsaturated FA & $66.72 \pm 2.45$ & $63.40 \pm 2.53$ & $61.98 \pm 2.62$ \\
\hline$\sum$ monounsaturated FA & $47.55 \pm 5.94$ & $48.60 \pm 6.16$ & $49.53 \pm 6.37$ \\
\hline$\sum$ polyunsaturated FA & $19.17 \pm 0.98$ & $14.80 \pm 0.80^{* *}$ & $12.45 \pm 0.73 * * *$ \\
\hline $\begin{array}{l}\text { Saturated FA/ } \\
\text { unsaturated FA }\end{array}$ & 0.50 & 0.58 & 0.61 \\
\hline
\end{tabular}

Notes: see Table 1.

Total lipid content in the the skeletal muscles of fish of third group (Table 5), the number of helminths in the intestines of which was 4 or more parasites was much smaller than in the skeletal muscles of fish of the control group $(\mathrm{P}<0.01)$. Reduction of total lipid content in skeletal muscles of carp of third group in comparison to the fish of first group was caused by a decrease in the content of triacylglycerols, free fatty acids and phospholipids ( $\mathrm{P}<0.05 ; \mathrm{P}<0.05 ; \mathrm{P}<0.01)$, while the content of monoand diacylglycerols increased significantly $(\mathrm{P}<0.001)$.

\section{Table 5}

Total lipid content and ratio of their individual classes in the skeletal muscle of the investigated fish, not infected and infected with $B$. acheilognathi $(\mathrm{x} \pm \mathrm{SD}, \mathrm{n}=4)$

\begin{tabular}{lccc}
\hline \multicolumn{1}{c}{ Lipid classes } & $\begin{array}{c}\text { Uninfected, } \\
\text { control }\end{array}$ & $\begin{array}{c}1-3 \text { parasites } \\
\text { per fish }\end{array}$ & $\begin{array}{c}>3 \text { parasites } \\
\text { per fish }\end{array}$ \\
\hline $\begin{array}{l}\text { Total lipids, g\% } \\
\quad \text { Lipid classes, } \%\end{array}$ & $5.80 \pm 0.26$ & $5.39 \pm 0.27$ & $3.74 \pm 0.37^{* *}$ \\
Phospholipids & $53.84 \pm 0.76$ & $51.34 \pm 0.80^{*}$ & $49.03 \pm 1.04^{* *}$ \\
Mono- and & $10.43 \pm 0.47$ & $13.78 \pm 0.84^{*}$ & $17.48 \pm 0.84^{* * *}$ \\
diacylglycerols & $8.68 \pm 0.55$ & $10.82 \pm 0.58^{*}$ & $12.31 \pm 0.57^{* *}$ \\
Free cholesterol & $10.47 \pm 0.90$ & $8.90 \pm 0.54$ & $6.60 \pm 0.84^{*}$ \\
Free fatty acids & $10.78 \pm 0.68$ & $8.77 \pm 1.33$ & $7.67 \pm 1.14^{*}$ \\
Triacylglycerols & $5.81 \pm 0.61$ & $6.39 \pm 0.49$ & $6.91 \pm 0.66$ \\
Cholesterol esterified & & & \\
\hline
\end{tabular}

Notes: see Table 1.

Similar changes in lipid content were found in the skeletal muscles of fish in second group compared to first group fish, however, differences in the content of phospholipids, mono- and diacylglycerols and free cholesterol were significant $(\mathrm{P}<0.05)$. These data mean that a severe Bothriocephalus infection in the skeletal muscles of carp causes not only disintegration of triacylglycerols, but also glycerophospholipids, as evidenced by their high content of mono- and diacylglycerols and low phospholipids, and also increases the oxidation of free fatty acids. and also increases the oxidation of free fatty acids. An increase in the relative content of free cholesterol in the skeletal muscles of fish in the third group compared to 
first group fish can be explained by the decrease in the relative content of triacylglycerols and phospholipids in the total amount of lipids. In general, the results obtained indicate the insufficient supply of this year's carp infected with Bothriocephalus with energy due to disruption of nutrient absorption of feed, including lipids and their antecessors.

Fatty acid composition in skeletal muscle of total lipids in the carp of the second, and especially of the third group, in comparison to the fish of the first group (Table 6) was characterized by a much higher content of saturated and monounsaturated fatty acids and lower content of polyunsaturated fatty acids $(\mathrm{P}<0.001)$. In particular, a notably higher content of myristic, palmitic and stearic acids $(\mathrm{P}<0.01 ; \mathrm{P}<0.05 ; \mathrm{P}<0.05)$, palmitoleic and oleic acids $(\mathrm{P}<0.05)$ and lower content of linoleic, linolenic, eicosamonoic, eicosadiene, eicosatetraic, eicosapentaenoic, docosapentaenoic, docosahexaenoic and lignoceric acids $(\mathrm{P}<0.001-0.05)$ was detected in skeletal muscles of fish from group 3 compared to fish from group 1.

\section{Table 6}

The content of fatty acids of total lipids of skeletal muscle of the investigated fish, not infected and infected with $B$. acheilognathi $(\%, \mathrm{x} \pm \mathrm{SD}, \mathrm{n}=4)$

\begin{tabular}{|c|c|c|c|}
\hline Fatty acid code & $\begin{array}{l}\text { Uninfected, } \\
\text { control }\end{array}$ & $\begin{array}{l}\text { 1-3 parasites } \\
\text { per fish }\end{array}$ & $\begin{array}{l}>3 \text { parasites } \\
\text { per fish }\end{array}$ \\
\hline $\mathrm{C}_{140}$ & $1.06 \pm 0.05$ & $1.38 \pm 0.06^{* *}$ & $1.55 \pm 0.09^{* *}$ \\
\hline $\mathrm{C}_{14: 1}$ & $0.59 \pm 0.05$ & $0.79 \pm 0.05^{*}$ & $0.92 \pm 0.07^{* *}$ \\
\hline $\mathrm{C}_{15: 0}$ & $1.00 \pm 0.03$ & $1.10 \pm 0.09$ & $1.18 \pm 0.04^{*}$ \\
\hline $\mathrm{C}_{16: 0}$ & $22.42 \pm 0.82$ & $24.80 \pm 0.86$ & $25.58 \pm 0.89^{*}$ \\
\hline $\mathrm{C}_{16: 1}$ & $5.18 \pm 0.12$ & $6.96 \pm 0.28^{* *}$ & $7.32 \pm 0.13^{* * *}$ \\
\hline $\mathrm{C}_{17.0}$ & $0.80 \pm 0.03$ & $0.90 \pm 0.11$ & $0.97 \pm 0.09$ \\
\hline $\mathrm{C}_{17: 1}$ & $0.44 \pm 0.06$ & $0.57 \pm 0.07$ & $0.74 \pm 0.05^{* *}$ \\
\hline $\mathrm{C}_{18: 0}$ & $8.84 \pm 0.36$ & $9.80 \pm 0.31$ & $11.23 \pm 0.27^{* *}$ \\
\hline $\mathrm{C}_{18: 1}$ & $36.47 \pm 0.55$ & $38.10 \pm 0.76$ & $38.83 \pm 0.69$ \\
\hline $\mathrm{C}_{1822}$ & $11.62 \pm 0.76$ & $7.34 \pm 0.56^{* *}$ & $5.65 \pm 0.62 * * *$ \\
\hline $\mathrm{C}_{183}$ & $1.25 \pm 0.17$ & $0.76 \pm 0.08^{*}$ & $0.62 \pm 0.14^{*}$ \\
\hline $\mathrm{C}_{20: 1}$ & $2.77 \pm 0.08$ & $1.92 \pm 0.10^{* * *}$ & $1.58 \pm 0.13^{* * *}$ \\
\hline $\mathrm{C}_{202}$ & $0.93 \pm 0.08$ & $0.67 \pm 0.09$ & $0.60 \pm 0.06^{*}$ \\
\hline $\mathrm{C}_{203}$ & $0.34 \pm 0.12$ & $0.12 \pm 0.01$ & $0.10 \pm 0.02$ \\
\hline $\mathrm{C}_{20: 4}$ & $1.94 \pm 0.06$ & $1.61 \pm 0.12 *$ & $0.82 \pm 0.08^{* * *}$ \\
\hline $\mathrm{C}_{20.5}$ & $0.68 \pm 0.09$ & $0.49 \pm 0.05$ & $0.44 \pm 0.03^{*}$ \\
\hline $\mathrm{C}_{223}$ & $0.30 \pm 0.08$ & $0.19 \pm 0.01$ & $0.14 \pm 0.01$ \\
\hline $\mathrm{C}_{22: 4}$ & $0.63 \pm 0.08$ & $0.39 \pm 0.08$ & $0.24 \pm 0.05 * *$ \\
\hline $\mathrm{C}_{225}$ & $0.55 \pm 0.06$ & $0.34 \pm 0.02 *$ & $0.33 \pm 0.02 *$ \\
\hline $\mathrm{C}_{22: 6}$ & $1.68 \pm 0.09$ & $1.34 \pm 0.05^{*}$ & $0.85 \pm 0.08^{* * *}$ \\
\hline $\mathrm{C}_{24: 1}$ & $0.51 \pm 0.06$ & $0.30 \pm 0.05^{*}$ & $0.31 \pm 0.01 *$ \\
\hline$\sum$ saturated FA & $34.12 \pm 4.19$ & $37.18 \pm 4.62$ & $40.51 \pm 4.78$ \\
\hline$\sum$ unsaturated FA & $65.88 \pm 2.42$ & $62.82 \pm 2.50$ & $59.49 \pm 2.55^{*}$ \\
\hline$\sum$ monounsaturated FA & $45.96 \pm 5.81$ & $48.64 \pm 6.08$ & $49.70 \pm 6.20$ \\
\hline$\sum$ polyunsaturated FA & $19.92 \pm 1.08$ & $14.18 \pm 0.69 * * *$ & $9.79 \pm 0.53 * * *$ \\
\hline $\begin{array}{l}\text { Saturated FA/ } \\
\text { unsaturated FA }\end{array}$ & 0.52 & 0.59 & 0.68 \\
\hline
\end{tabular}

Notes: see Table 1.

Similar differences in the content of these fatty acids in the skeletal muscles of fish of second group compared to first group fish were less pronounced, although a number of them are statistically significant. Because of the differences in the content of phospholipids and esterified cholesterol, lipid classes, characterized by high levels of polyunsaturated fatty acids, in the test group fish compared to the control group fish were relatively small or completely absent, then the content of polyunsaturated fatty acids in the skeletal muscles of fish of the second $(\mathrm{P}<0.001)$ and third $(\mathrm{P}<0.001)$ groups was considerably less than in skeletal muscles of fish of the first group, which can be explained by the negative impact the products of the vital activity of the Bothriocephalus on their absorption and metabolism. Reduction of the absorption of feed lipids and their antecessor in the gut of Bothriocephalus infected fish testifies the lower lipid content $(\mathrm{P}<0.001-0.05)$ and a smaller proportion of polyunsaturated fatty acids $(\mathrm{P}<0.001)$ in their composition in skeletal muscles of fish of the second and especially third groups, than in skeletal muscles of fish of the first group. Metabolism disorders of polyunsaturated fatty acids in skeletal muscles of fish of the second and third groups in comparison with the fish of the first group indicates lower content of lipid C20- and C22-polyunsaturated fatty acids, which are synthesized from linoleic and linolenic acids.

\section{Discussion}

One of the important issues in practice when considering the relationship between the parasite and the host is the pathogenicity of parasites, the level of which depends on the presence or absence of equilibrium in the parasite-host system. There are three main types of relationship between the parasite and the host, which determine the position of the system as a whole: 1) the parasite can be suppressed by the host, whose resistance is high enough; 2) the normal state of the body is not sufficiently resistant, the host can be affected by a parasite that causes the disease and even the death of fish; 3) a certain balance can be struck between the parasite and the host, when the host resistance is so high that it could greatly limit the pathogenic impact of the parasite, minimizing it. Transition from one state to another is conditioned by the evolution of the parasite-host system itself, exposed to natural selection, which saves first and foremost only these systems in which a certain equilibrium takes place, which benefits both of its members. The preservation of the parasite-host system is, on the one hand, achieved by parasite adaptation to the host, which means its specificity, on the other hand, by means of the host's adaptation to the parasite, which reduces pathogenicity and results in equilibrium (Hansen et al., 2006; Britton et al., 2011; Zargar et al., 2011).

Investigation of the effect of Bothriocephalus invasions on adaptation of metabolism lipids and physiological functions in carp depends on the number of $B$. acheilognathi helminths in the intestine. According to some authors (Zargar et al., 2011), the survival of this year's carp largely depends on their live weight, which is most affected by the level and the value of feeding and infectious and invasive diseases (Steffens \& Wirth, 2007; Pegg et al., 2015).

It is now known that a significant amount of metabolic energy in the body of fish is deposited in the process of growth and especially at the end of the growing season in the form of triacylglycerols in their tissues - fat, hepatopancreas, skeletal muscle (Tocher, 2003) - and is used in energy processes during the winter starvation (Kminova et al., 2001). With underweight carp when infected with Bothriocephalus, storage of reserve lipids in the tissues significantly decreases (Hansen et al., 2006), which will have a negative impact on their ability to meet their needs in metabolic energy in winter, and thus - on their survival. Change in the structure of lipids (within physiological limits) is one of the aspects of adaptive reactions that provide the body with the ability to survive in the face of different ecological factors. Compensatory lipid mechanism facilitates support of membranes (for instance, instability, permeability, mobility of membrane components, activity of ion transport and membrane enzyme activity) in such a way that the membranes are able to perform optimally their various functions (Murzina et al., 2013).

The novelty of our results lies in detection of decrease in the total lipid content of carp tissues, infected with Bothriocephalus, which is caused by a decrease relative the content of phospholipids and triacylglycerols, while the relative content of mono- and diacylglycerols, free and esterified cholesterol increases. In the tissues of fish, the content of free fatty acids is significantly reduced. From this it follows that invasion of carp by Bothriocephalus leads to reduced synthesis in their tissues not just of reserve lipids (triacylglycerols), and also structural (phospholipids).

Our research found that the total lipids of the studied carp tissues, infected with Bothriocephalus, compared to not infected fish, are significantly lower than the content of linoleic, linolenic acids, their derivatives, and more unsaturated fatty acids. As is known, polyunsaturated fatty acids are essential components of glycerophospholipids and reducing their intracellular content may cause a decrease in their synthesis. Apart from this, polyunsaturated fatty acids play a physiological significance in normal operation and structural lipid stability of cell membranes (Suleimanova et al., 2018). Another factor the effect of which is to reduce the content of phospholipids and triacylglycerols in tissues infected with Botriocephalus fish, is a decrease of glycerolphosphate production due to a decrease of glucose metabolism. The third factor which affects the synthesis of triacylglycerols in carp tissues, infected with Bothriocephalus, may be insufficient ATP production, through which the use of fatty acids is ensured in the acylation processes in lipid synthesis. This is evidenced by our finding of a significantly higher content of monoacylglycerols and diacylglycerols in tissues of fish infected with Bothriocephalus than in the tissues of healthy fish. 
Analysis of the obtained results does provide a sufficient explanation for the significantly higher level of free and esterified cholesterol in all tissues of carp infected with Bothriocephalus, compared to their content in the tissues of uninfected fish. However, these data hold considerable interest given their importance. It is known that the lipids of cell membranes of animal tissues, including fish, represented by phospholipids and cholesterol (Murzina et al., 2016), and the relationship between content of these classes of lipids in membranes significantly affects their physical and chemical composition, permeability and metabolic activity (Böhm et al., 2014; Hashimoto \& Hossain, 2018). If it is considered that in the lipids of the tissues of this year's carp, infected with Botriocephalus, compared to total tissue lipids of uninfected fish, a significantly lower content of all polyunsaturated fatty acids was found, then we can conclude that helminths have a negative impact on the structure and function of tissue cell membranes, and thus on the physiological state of fish and metabolism in their body. A particularly negative impact of Bothriocephalus for the life of this year's carp can manifest in winter, which is an important liquid state of cell membranes and fish tissue in the process of their adaptation to low temperature.

The obtained results show that the negative impact of Bothriocephalus on the life of the carp is caused by impaired lipid metabolism in their body. Negative influence of Bothriocephalus for the life of carp is as follows: reduction of synthesis of structural lipids, which adversely affects their growth; reduction of stocks of triacylglycerols in fish tissues, which negatively affects their needs for metabolic energy in winter; reducing the liquid state of cell membranes, which adversely affects their adaptation to low temperature in winter; impaired synthesis of eicosanoids (prostaglandins, leukotrienes), which play an important role in the regulation of metabolism and physiological functions in fish (Tocher et al., 2015; Husain et al., 2016); impaired absorption of lipids in the intestine due to the decrease in phospholipid production, that are part of bile, which is important in the emulsification of lipids upon their cleavage.

Separate tissues and organs of fish differ in the fatty acid composition of their lipids. It is known that in the process of digestion of feed in the digestive canal, feed lipids are partially hydrolyzed, and others pass through the intestinal walls in the non hydrolyzed form. Part of the hydrolyzed lipids, passing through the intestinal wall, are resynthesized again from its original components (Murzina et al., 2013; Zajic et al., 2013), other hydrolyzed lipids are subject to specific transformations directly in the intestine (Murzina et al., 2013)

Fatty acid composition of total lipids in tissue of carp intestines depends on the intensity of invasion by parasites. In both groups of infected fish, compared to not infected, there is the same upward trend in amounts of saturated fatty acids due to myristic (C14:0), pentadecanoic (C15:0), margaric (C17:0) and especially palmitic (C16:0) and stearic (C18:0). In cestodes of fish there was an increase in the content of oleic acid (C18:1). This indicator tissue of the intestine of infected fish compared to not infected increased by $12.9-19.6 \%$. The content of others is growing, monounsaturated fatty acids: palmitoleic (C16:1), heptadecenoic (C17:1). At the same time, infected fish revealed a significant decrease in polyunsaturated acids: linoleic (C18:2), linolenic (C18:3), arachidonic (C20:4), docosahexaenoic (C22:6). In the absence of linoleic acid, carp cannot synthesize other polyunsaturated acids $\omega 3$ series, leading to an increase in oleic and palmitic acids (Tocher, 2003; Lei et al., 2015). This dependency, as we can see is observed with infection of fish with Botriocephalus.

Based on these observations (Luo et al., 2009), lipids and glycogen can be considered as an important source of energy in the liver and considering that protein may be predominantly mobilized in muscle, then lipids play an important role as energy reserves throughout the body.

The presented results of the study (Lavryn et al., 2014) about lipid content and the ratio of their classes in the liver of the fish under study (carp, crucian, perch, pike) from the small rivers of the West Podillya indicates a lower predicted level of adaptation to environmental conditions. Directing of lipid metabolism towards lipolysis indicates formation of catabolic stress syndrome in the conditions of intoxication. However, in the hepatopancreas of carp infected with Bothriocephalus, the total lipids content decreases due to the pathogenic factor. This decrease is due to the lower content in the hepatopancreas of this year's carp of triacylglycerols and phospholipids, which make up more than $60 \%$ of the total lipids in this fish organ and the formation of catabolic stress syndrome. Our results on individual lipid classes in the hepatopancreas are consistent with the data (Scholz et al., 2012) about the decrease in liver content phospholipids and triacylglycerols that are infected with helminths.

According to histological studies (Britton et al., 2011; Gaikwad et al., 2016; Ahmad et al., 2018), parasites cause depletion, fragmentation and necrosis of the argyrophilic fibers of its stroma, associated with selection helminth phospholipases, which causes the permeability of cell membranes, without destroying them completely (Sisolatin et al., 2017). Hepatopancreas lipids of carp, infected with $B$. acheilognath $i$ are characterized by a higher content of saturated fatty acids (C14:0, C16:0, C18:0) and a lower content of arachidonic (C20:4), linolenic (C18:3) and linoleic (C18:2), which is associated with a decrease in the source for synthesis of a number of polyunsaturated fatty acids, especially docosahexaenoic (C22:6).

According to the hypothesis of Bradbury (2011), increase of docosahexaenoic acid in membrane phospholipids in ectotherms is a universal answer for any (not just temperature) effect, aimed at regulating the processes of metabolism at the subcellular, cellular and tissue levels. Adaptive content changes of docosahexaenoic acid in membrane lipids occur on a scale like "macrotime" - specific idioadaptations, while "microtime" is functional "tuning" of the body to a certain level of metabolic activity. Nature opted out on one of the most important "adaptation substances" (adaptogens), namely, docosahexaenoic acid (Kminova et al., 2001; Watanabe, 1993; Sysoliatin \& Khizhnyak, 2017).

In the total lipids of skeletal muscle in carp infected with Bothriocephalus the content of C18-, C20-, C22-polyunsaturated fatty acids is likely to decrease and the content of saturated (C14:0, C16:0, C18:0) and monounsaturated (C16:1, C18:1) fatty acids that have high metabolic activity is increased. The extent of these changes depends on the degree of intensity of infection of the fish. Modifications of fatty acid content of lipids that were detected in muscle of carp can be explained by involvement of fatty acids in systems of reactivity of an organism to actions of environmental factors, which ensures optimum work all metabolic processes (Sysoliatin et al., 2017). Our results are consistent with those of other authors (Zajic et al., 2013, Kainz et al., 2017) about increased lipid mobilization, as well as content reduction of polyenes fatty acids in lipids of carp tissues. They indicate of significant disturbances in the exchange of reserve and structural lipids and polyunsaturated fatty acids in skeletal muscle of carp infected with Bothriocephalus. During the winter fasting in carp a significant decrease is observed in the number of saturated (pentadecanonic, margaric) and many unsaturated fatty acids from monoenes myristoleic, palmitoleic, of polyenes - linolenic (more than twice) and arachidonic (almost four times) (Tanck et al., 2000; Al-Niaeemi \& Dawood, 2017).

Therefore, the results we have obtained proves that the B. acheilognathi parasite in the intestines of the carp can significantly affect the power supply of the host depending on the intensity of the damage by helminths, limiting its capabilities when consuming feed - necessary cofactors, substrates and macroergies, leading to impaired lipid metabolism.

\section{Conclusion}

The content of total concentration of lipids and lipid fractions in the tissue of intestines, hepatopancreas and skeletal muscles of carp depends on intensity of $B$. acheilognathi helminth damage. In the case of Bothriocephalus infected carp, the total lipid content, structural lipids (phospholipids) and reserve energy sources (triacylglycerols) decreases and the content of free and esterified cholesterol, mono- and diacylglycerols increases.

The intestinal tissue of carp infected by helminth $B$. acheilognathi contains less linoleic, linolenic, arachidonic, penta- and hexanoic unsaturated fatty acids, and the level of unsaturated fatty acids decreases and the content of saturated fatty acids inceases, which leads to an increase in the saturation factor. Lipids of hepatopancreas of carp in cases of infection with $B$. acheilognathi, are characterized by a high content of saturated fatty acids (C14:0, C16:0, C18:0) and a lesser content of unsaturated arachidonic (C20:4), linolenic (C18:3) and linoleic (C18:2), which is related to a decrease in the source for the synthesis of a number of polyunsaturated fatty acids, especially docosahexaenoic (C22:6). In common lipids of skeletal muscle of carp, the content of C18-, C20-, C22-polyunsaturated 
fatty acids decreases and the content of saturated (C14:0, C16:0, C18:0) and monounsaturated $(\mathrm{C} 16: 1, \mathrm{C} 18: 1)$ fatty acids increases, and the extent of these changes depends on intensity of damage to the fish by $B$. acheilognathi.

\section{References}

Agrawal, A. A., Ackerly, D. D., Adler, F., Arnold, A. E., Cacéres, C., Doak, D. F., Post, E., Hudson, P. J., Maron, J., Mooney, K. A., Power, M., Schemske, D., Stachowicz, J., Strauss, S., Turner, M. G., \& Werner, E. (2007). Filling key gaps in population and community ecology. Frontiers in Ecology and the Environment, 5(3), 145-152.

Ahmad, F., Fazili, K. M., Sof, O. M., Sheikh, B. A., \& Sof, T. A. (2018). Distribución y patología causada por Bothriocephalus acheilognathi, Yamaguti 1934 (Cestoda: Bothriocephalidae). Revisión bibliográfica. Revista Veterinaria, 29(2), 142-149.

Al-Niaeemi, B. H., \& Dawood, M. H. (2017). Total lipids estimation and fatty acids analysis of Bothriocephalus acheilognathi, a parasitis tapeworm of the common carp (Cyprinus carpio L., 1758) from tigris river-mosul city. World Journal of Pharmacy and Pharmaceutical Sciences, 6(9), 1641-1651.

Arkhipov, A. V., \& Antonov, A. A. (1979). Izuchenie lipidov i lipidnovo obmena u selskochozctvennuch zhivotnux i ptitz s primeneniem tonkosloynoy i gazozhidkostnoy chromatodrafii [The study of lipids and lipid metabolism in farm animals and birds using thin-layer and gas-liquid chromatography]. Moscow (in Russian).

Böhm, M., Schultz, S., Koussoroplis, A.-M., \& Kainz, M. J. (2014). Tissue-specific fatty acids response to different diets in common carp (Cyprinus carpio L.). PLoS One, 9(4), e94759.

Bradbury, J. (2011). Docosahexaenoic acid (DHA): An ancient nutrient for the modern human brain. Nutrients, 3(5), 529-554.

Britton, J. R., Pegg, J., \& Williams, C. F. (2011). Pathological and ecological host consequences of infection by an introduced fish parasite. PLoS One, 6(10), e26365.

Davies, K. J. A. (2016). Adaptive homeostasis. Molecular aspects of medicine, 49, 1-7.

Dey, S., Misra, K. K., \& Homechoudhuri, S., (2015). Analysis of major lipid classes and their fatty acid composition of an Indian minor carp Puntius sophore in order to evaluate its nutritional aspects. International Journal of Advance Research in Biological Science, 2(8), 100-119.

Folch, J., Lees, M., \& Stanley, S. G. (1957). A simple method for the isolation and purification of total lipides from animal tissues. Journal of Biological Chemistry, 226 (1), 497-509.

Gaikwad, P. R., Sonune, M. B., \& Nagmote, S. R. (2016). Histopathological effects of the Cestode parasites on fishes from the Amravati region of Vidarbha (MS) India. International Journal of Life Sciences, 4(4), 602-605.

Hansen, S. P., Choudhury, A., Heisey, D. M., Ahumada, J. A., Hoffnagle, T. L., \& Cole, R. A. (2006). Experimental infection of the endangered bonytail chub ( $\mathrm{Gi}$ la elegans) with the Asian fish tapeworm (Bothriocephalus acheilognathi): Impacts on survival, growth, and condition. Canadian Journal of Zoology, 84(10), 1383-1394.

Hashimoto, M., \& Hossain, S. (2018). Fatty acids: From membrane ingredients to signaling molecules. In: Biochemistry and Health benefits of fatty acids. Viduranga Waisundara. IntechOpen.

Hassan, H. F., Hashim, D. S., \& Abdullah, S. M. A. (2016). Identification of some Iraqi Fish parasites by using biochemical and molecular protocols. International Journal of Current Research and Academic Review, 4(1), 54-64.

Hrytsyniak, I. I., Smolianinov, K. B., \& Yanovich, V. G. (2010). Obmin lipidiv u ryb [Lipid metabolism in fish: monograph]. Triad Plus, Lviv (in Ukrainian).

Hu, W., Mai, K.-S., Luo, Z., Zheng, J.-L., Chen, Q.-L., \& Pan, Y.-X. (2016). Effect of waterborne copper on lipid metabolism in hepatopancreas and muscle of grass carp Ctenopharyngodon idella. Aquaculture Research, 48(4), $1458-1468$.

Kainz, M. J., Hager, H. H., Rasconi, S., Kahilainen, K. K., Amundsen, P.-A., \& Hayden, B. (2017). Polyunsaturated fatty acids in fishes increase with total lipids irrespective of feeding sources and trophic position. Ecosphere, 8(4), $\mathrm{e} 01753$.

Kates, M. (1975). Technika lipidologii. Vidilenie, analis i indentifikatsia lipidov [Technique of lipidology. Isolation, analysis and identification of lipids]. Mir, Moscow (in Russian).

Klein, S. L. (2005). Parasite manipulation of host behavior: Mechanisms, ecology, and future directions. Behavioural Processes, 68(3), 219-221.

Kmínková, M., Winterová, R., \& Kučera, J. (2013). Fatty acids in lipids of carp (Cyprinus carpio) tissues. Czech Journal of Food Sciences, 19(5), 177-181.

Kuchta, R., Choudhury, A., \& Scholz, T. (2018). Asian fish tapeworm: The most successful invasive parasite in freshwaters. Trends in Parasitology, 34(6), $511-523$.
Lei, C. X., Tian, J. J., Ji, H., Chen, L. Q., \& Du, Z. Y. (2015). Dietary $\alpha$-linolenic acid affects lipid metabolism and tissue fatty acid profile and induces apoptosis in intraperitoneal adipose tissue of juvenile grass carp (Ctenopharyngodon idella). Aquaculture Nutrition, 23(1), 160-170.

Liavrin, B. Z., Senyk, Y. I., Khomenchuk, V. O., \& Kurant, V. Z. (2014). Vmist nepoliarnykh lipidiv u tkanynakh pechinky deiakykh vydiv ryb malykh richok Zakhidnoho Podillia [Content of nonpolar lipids in liver tissues of some fish species of the small rivers of the West Podillya]. Hydrobyolohycheskyi Zhurnal, 50(6), 60-66 (in Ukrainian).

Luo, Z., Tan, X.-Y., Wang, W.-M., \& Fan, Q.-X. (2009). Effects of long-term starvation on body weight and body composition of juvenile channel catfish, Ictalurus punctatus, with special emphasis on amino acid and fatty acid changes. Journal of Applied Ichthyology, 25(2), 184-189.

Marenkov, O. N. (2018). Ecological and biological aspects of zander and Volga zander reproduction under conditions of the Zaporizhzhia reservoir (Ukraine). Ukrainian Journal of Ecology, 8(1), 441-450.

Murzina, S. A., Pekkoeva, S. N., Kondakova, E. A., Nefedova, Z. A., Filippova, K. A., Nemova, N. N., Orlov, A. M., Berge, J., \& Falk-Petersen, S. (2020). Tiny but fatty: Lipids and fatty acids in the daubed shanny (Leptoclinus maculatus), a small fish in svalbard waters. Biomolecules, 10(3), 368.

Murzina, S., Nefedova, Z., Falk-Petersen, S., Ripatti, P., Ruokolainen, T., Pekkoeva, S., \& Nemova, N. (2013). Lipid status of the two high latitude fish species, Leptoclinus maculatus and Lumpenus fabricii. International Journal of Molecular Sciences, 14(4), 7048-7060.

Murzina, S., Nefedova, Z., Pekkoeva, S., Veselov, A., Efremov, D., \& Nemova, N. (2016). Age-specific lipid and fatty acid profiles of atlantic salmon juveniles in the Varzuga river. International Journal of Molecular Sciences, 17(7), 1050.

Pegg, J., Andreou, D., Williams, C. F., \& Britton, J. R. (2015). Temporal changes in growth, condition and trophic niche in juvenile Cyprinus carpio infected with a non-native parasite. Parasitology, 142(13), 1579-1587.

Pukalo, P., \& Shekk, P. (2018). Parasitic diseases of fish in the ponds of farms of the Lviv regional fishery plant. Scientific Messenger of LNU of Veterinary Medicine and Biotechnologies, Series Veterinary Sciences, 83, 141-144.

Scholz, T., Kuchta, R., \& Williams, C. (2012). Bothriocephahus acheilognathi. In: Fish parasites: Pathobiology and protection. CABI, Wallingford. Pp. 282-297.

Sidorov, V. S., Lizenko, E. I., \& Bolgova, O. M. (1981). Tipovye metody isledovania produktivnosti vidov rib v predelah ich arealov [Typical methods of research of productivity of fish species within their ranges]. Part 4. Vilnius (in Russian).

Stahl, E. (1965). Chromatografia v tonkih sloyah [Chromatography in thin layers]. Mir, Moscow (in Russian).

Steffens, W., \& Wirth, M. (2007). Influence of nutrition on the lipid quality of pond fish: Common carp (Cyprinus carpio) and tench (Tinca tinca). Aquaculture International, 15(3-4), 313-319.

Suleimanova, R., Melnychuk, D., \& Kalachniuk, L. (2018). Indices of fatty acids spectrum of lipids in the blood serum of sterlet of different age. Eureka: Life Sciences, 2, 3-8.

Sysoliatin, S. V., Midyk, S. V., \& Khyzhnyak, S. V. (2017). Influence of hypoxia and hypercapnia on fatty acid composition of lipids in white muscles of common carp Cyprinus carpio. Problems of Cryobiology and Cryomedicine, 27(3), 195-202.

Sysolyatin, S. V., \& Khyzhnyak, S. V. (2017). Fatty acid composition of total lipids in liver of carp (Cyprinus carpio L.) under artificial hibernation. Reports of the National Academy of Sciences of Ukraine, (8), 102-105.

Tanck, M. W. T., Booms, G. H. R., Eding, E. H., Bonga, S. E. W., \& Komen, J. (2000). Cold shocks: A stressor for common carp. Journal of Fish Biology, 57(4), 881-894.

Tocher, D. R. (2003). Metabolism and functions of lipids and fatty acids in teleost fish. Reviews in Fisheries Science, 11(2), 107-184.

Tocher, D. R., \& Glencross, B. D. (2015). Lipids and fatty acids. In: Lee, C.-S., Lim, C., Gatlin, D. M., \& Webster, C. D. (Eds.). Dietary nutrients, additives, and fish health. Wiley. Pp. 47-94.

Vlizlo, V. V., Fedoruk, R. S., \& Ratych, I. B. (2012). Laboratomi metody doslidzhen u biolohii, tvarynnytstvi ta veterynarnii medytsyni [Laboratory methods of research in biology, animal husbandry and veterinary medicine]. Spolom, Lviv (in Ukrainian).

Watanabe, T. (1993). Importance of docosahexaenoic acid in marine larval fish. Journal of the World Aquaculture Society, 24(2), 152-161.

Zajic, T., Mraz, J., Sampels, S., \& Pickova, J. (2013). Fillet quality changes as a result of purging of common carp (Cyprinus carpio L.) with special regard to weight loss and lipid profile. Aquaculture, 400-401, 111-119.

Zargar, U. R., Chishti, M. Z., Yousuf, A. R., \& Ahmed, F. (2011). Infection level of the Asian tapeworm (Bothriocephalus acheilognathi) in the cyprinid fish, Schizothorax niger, from Anchar Lake, relative to season, sex, length and condition factor. Parasitology Research, 110(1), 427-435. 